\title{
11. Social entrepreneurship as sustainability agency $^{1}$

\author{
Hanna Lehtimäki, Subhanjan Sengupta, Ville-Veikko \\ Piispanen and Kaisa Henttonen
}

\section{INTRODUCTION}

In this chapter, we discuss social entrepreneurs as sustainability agents. Sustainability of business is increasingly becoming a concern for all companies, not just for social enterprises, because customers, citizens and policymakers are expecting improvements in sustainable performance from companies (Bocken et al., 2016; Kapitan et al., 2019). In the past, business has not been considered so much as the solution for the climate crises, pollution, or declining biodiversity, but rather, as a problem for various social and environmental outcomes and benefits at the expense of society. Now, a close connection between business and society is becoming increasingly important in legitimizing the business operations.

Michael Porter (2008), who has, for decades, been at the forefront of research on competitive strategy, argues that the competitiveness of a company and the wellbeing of the surrounding community are intertwined, not a zero-sum game. A community needs businesses to provide jobs and wealth creation opportunities for its citizens. Business needs the community to create demand for its products and to provide the required public assets and a supportive environment (Porter \& Kramer, 2006). The mutual interest for the long-term survival of business and the wellbeing of citizens and nature sets a demand for sustainable business, and, in this, research on social entrepreneurship becomes interesting. Social enterprises are non-profit, government or privately owned companies that run with a mission to create both social and economic value. They operate with a dual, social and economic, or even triple purpose, if environmental value creation is also included, as it is in the triple-bottom-line definition of sustainability (WCED, 1987).

Examining social entrepreneurs as sustainability agents calls for a discussion on agency in sustainability transitions. The World Commission on Environment and Development (WCED) has defined sustainability as development that meets the needs of the present without compromising the ability of future generations to meet their needs (WCED, 1987). Drawing attention to profit, people and planet, this definition has become established as the triple-bottom-line of sustainability, according to which the performance of a company is to be evaluated based on social, ecological, and economic sustainability over time.

Interestingly, sustainability transition literature shows interest mainly in large-scale changes, where agency commonly refers to the actions of collective actors, in the form of social movements and large formal organizations in public or private sectors (Geels, 2020). However, Geels (2020) argues also that attention to micro-level agency is needed for understanding the unfolding nature of sustainability transition close to the ground. Drawing on conceptualization on micro-foundations of sustainability transition, we examine the sustainability 
agency of social entrepreneurs as a capacity to act and as agency situated in and shaped by contexts.

In the next section, we outline how the literature review was conducted in this study. Next, we present an overview of research on social entrepreneurship highlighting the contested and hybrid logics in the concept. Then we discuss social entrepreneurs as pursuing the dual logic of social and economic value and explore how hybridity in social entrepreneurship opens opportunities for sustainability agency that incorporates social, economic, and environmental value creation. We then examine the sustainability agency of social entrepreneurs as a capacity to act as agency situated in and shaped by the context. Finally, we draw together insights from social, institutional, and sustainable entrepreneurship perspectives, and conclude this review with how social entrepreneurship can be seen as a sustainability agency.

\section{METHODOLOGY}

We base this study on a literature search done in late 2019 on the EBSCOhost Research database and the Scopus database (which includes ScienceDirect and Elsevier) with certain inclusion and exclusion criteria, and with a search for the keywords 'social entrepreneurship', 'social entrepreneur', 'sustainability', and 'agency' in the abstract and title (Table 11.1). The following three combinations of keywords were used in EBSCO and Scopus: (a) 'social entrepreneurship', 'social entrepreneur', and 'sustainability'; (b) 'social entrepreneurship', 'social entrepreneur', and 'agency'; and (c) 'social entrepreneurship', 'sustainability', and 'agency'. The purpose was to identify the most relevant research articles which revealed social entrepreneurship as a work of societal and institutional change for creating a sustainable society and environment, while also working towards a triple-bottom-line objective.

\section{Table $11.1 \quad$ Database search and selection of papers}

\begin{tabular}{llcl}
\hline Databases searched & Keywords searched in & Search results & Most relevant to review question \\
\hline EBSCO & Title, abstract & 323 & \\
SCOPUS & Title, abstract & 460 & \\
Inclusion & Exclusion & & Keywords searched \\
Full text & Editorials & & Social entrepreneurship \\
Scholarly peer reviewed & Commentaries & Social entrepreneur \\
Conceptual papers & Viewpoint articles & & Sustainability \\
Empirical papers & Grey literature & Triple-bottom-line \\
Literature reviews & Book reviews & Agency \\
Only English articles & News articles & & \\
\hline
\end{tabular}

A careful review of the abstracts (which ranged across multifarious issues in social entrepreneurship and sustainability) led us to finally select 45 articles which informed us on the key review question: What does literature reveal about the micro-level agential change brought about by social entrepreneurs and social enterprises for sustainability? While this is part of an ongoing work in a larger project, this chapter refers to some key empirical and theoretical literature to shape an argument on how researchers can view social entrepreneurship as sustainability agency to contribute to both the sustainability and entrepreneurship literature. 
The review led us to realize that the idea of 'sustainability' and 'agency' as co-existing in the context of 'social entrepreneurship' is still rarely articulated and examined.

\section{SOCIAL ENTREPRENEURSHIP}

In this section, we provide a brief overview of what makes social entrepreneurship a contested concept and how is it hybrid in characteristic. We then examine how hybridity is managed by social enterprises for sustainability and the role of social entrepreneurs as change agents. We conclude this section with a discussion on sustainability in social entrepreneurship.

\section{A Contested Concept}

After the two devastating world wars, the idea of social welfare became an important paradigm in most regimes. It was implemented through activities of non-government organizations, civil society movements, and the church, all of which put effort into dealing with the despair, inequality, unemployment, and poverty due to the wars in Europe (Defourny \& Nyssens, 2010). Over time, people started questioning the ability of the state and non-profit organizations to run operations so that the pressing socio-economic needs of people were met. The non-government social purpose ventures started to implement earned income strategies to balance the government cuts and the fluctuating organizational or individual donations (Boschee, 1998). In the 1980s, the concept of social enterprise emerged as a complementary organization to non-profit organizations with a market-oriented approach, skills in financial planning and management, and the ability to reduce dependency on grants alone for social welfare purposes (Helmsing, 2015; Zietlow, 2001). In the 2000s, the concept has raised a lot of interest in the society due to the freshness of the perspective and the contested nature of the dual logic of economic and social mission (Austin et al., 2006; Kittilaksanawong et al., 2012).

Examples of social enterprises vary from country to country. For example, in the European context alone, there are different definitions on what is a social enterprise. The European approach, known as EMES (Emergence of Social Enterprise in Europe), considers enterprises initiated by citizens for producing specific goods and services for communities as social enterprises. In the UK, for example, social enterprises get registered as CICs (Community Interest Companies), which identifies social enterprises as those who use their assets for public good and who reinvest the surpluses in the business or in the community rather than aiming for profit maximization of owners and shareholders (Sengupta et al., 2018). In Finland, in turn, at least $30 \%$ of the employees in a social enterprise must be disabled or long-term unemployed before the enterprise can be officially registered as such. Further, there are strict rules on what kind of compensation enterprises can pay their employees and how those payments can be subsidized by the governmental agencies (Finlex, 2020). In Finland, as in other countries as well, social enterprises act in a variety of fields. They may be care homes for the elderly, laundry services, recycling companies for information technology equipment or cooperatives for transcribing and proofreading services, to mention a few.

In Europe, most countries have a law, an act of parliament or a strategy on social enterprises, but the national definitions of social enterprises vary significantly from one country to another, and not all countries have an official national definition for social entrepreneurship (European Commission, 2020). The European Commission states that, due to the multiplicity of factors 
related to the operations and the national contexts of a social enterprise, it is impossible to provide a unified, uniform, and exhaustive picture of the dimensions of the social enterprise at European level (European Commission, 2020). When estimating the information on social enterprises' turnover, the data is very limited. There is high reliability of data only from Estonia, Hungary, Ireland, Italy, the Netherlands, and Portugal (European Commission, 2020).

In academic research, starting with the seminal article by Dees (1998), the past two decades have established social entrepreneurship as a confluence of the sensitivities of the third sector and the dynamics of market principles. Despite the continuously growing interest, the field is still a nascent area of research and there is no cohesive definition of the term (Hota et al., 2019). Some researchers consider social enterprises as those creating social value through social innovation with or without commercial activities, while others consider social entrepreneurs as for-profit enterprises serving the poor and marginalized in society. For others, social enterprises are not-for-profits which inhibit for-profit activities to generate revenue for sustainability.

Choi and Majumdar (2014) argued that a single definition for social entrepreneurship is not possible since social enterprises arguably exist in three different forms: (a) enterprises creating social value through social innovation, with or without commercial activities; (b) for-profit enterprises serving the poor; and (c) not-for-profit enterprises with some commercial activities to generate revenue. Hence, they conceptualized social entrepreneurship as a cluster of five sub-concepts: social value creation, market orientation, social innovation, the social enterprise organization, and the social entrepreneur. Social value creation is a prerequisite for social entrepreneurship. It entails a social mission addressing pressing social issues and problems in a disadvantaged community, usually upholding values such as dignity, equality, liberty, and tolerance. Being market oriented brings with it a business-like discipline, market awareness, a heightened sense of resourcefulness, managerial efficiency and effectiveness, and self-sufficiency. Being socially innovative means being non-traditional and disruptive in a traditional context of social service. It also entails the Schumpeterian idea of entrepreneurs as individuals who create new models that bring changes in economy. The social entrepreneur is important in this cluster concept as she/he is viewed as the initiator and innovator who pushes through social change, innovation, and resourcefulness. Finally, the sense and structure of an 'organization' differentiates it from activist movements. It can exist in any legal form, if it is socially value creating, socially innovative, and market oriented.

The contested nature and the nascent stage of evolution of the social entrepreneurship phenomenon has triggered an explosion of descriptive and conceptual literature over empirical studies. The definition of social entrepreneurship builds on the nature of the mission, which operates with a tension between market orientation and social orientation, and challenges the existing institutionalized structures while seeking to create social and economic value (Austin et al. 2006; Hill et al., 2010; Massetti, 2008). Being a multi-dimensional construct comprising entrepreneurial attributes and abilities to take risks in sustainably pursuing both social and economic missions in close engagement with beneficiaries, social enterprises are considered to be affected by diverse contextual complexities (Alvord et al., 2004; Miller et al., 2012; Mort et al., 2003; Tan et al., 2005). 


\section{Managing Hybridity for Sustainability}

A common thread of acceptance across literature is that social enterprises are hybrid organizations with processes and solutions for social value creation and market orientation at varying degrees to accomplish a double-bottom-line: economic and social bottom lines (eg. Bacq \& Janssen, 2011; Choi and Majumdar, 2014; Dacin et al., 2010; Doherty et al., 2014; Goyal and Sergi, 2015; Kittilaksanawong et al., 2012; Mook et al., 2015; Uygur \& Marcoux, 2013; Zahra et al., 2009; Zainon et al., 2014). As hybrid organizations, social entrepreneurs work on a combination of systems of economic exchange that include redistribution of resources, reciprocity towards the community, market orientation and social value orientation, and creating mutual benefit for the beneficiaries and the entrepreneur (Bull \& Ridley-Duff, 2019). One solution to successful management of blending profit making and social mission is striking a balance by entitling investors to a modest, below-market return, and the entrepreneur to minimum necessary capital (Reiser \& Dean, 2013). Another approach towards the effective management of a double-bottom-line, with a specific reference to microfinance, is employing cost-effective methods for assessing social impact: methods that meet the minimum required reliability, generate sufficient information necessary for taking better decisions, and come at reasonable cost (Copestake et al., 2005).

Zahra et al. (2009) defined three different types of social enterprise, that is, social bricoleur, social constructionist, and social engineer. The definition of the first typology, social bricoleur, draws from the understanding that the intimate knowledge of local environmental conditions and resources have a critical link to acting towards the opportunities and weaknesses in the local society. They are motivated by the possibility of changing matters in their local context and within their own expertise and networks. Social bricoleurs are important because many social needs are not scalable to outside the region or context, and require local change agents also to detect and address them. The actions of social bricoleurs thereby help collectively in maintaining social harmony and moving towards a more meaningful social equilibrium. The small scale and local scope allow for a quick response to locally important issues, and effectively direct attention to the local laws and regulations in enabling or restricting the operations and the skills and resources available to the social bricoleur.

The second typology, social constructionists, are seeking alternative ways to provide goods and services focusing on the social needs that governments, agencies, and businesses cannot fulfil. They operate at a small to large-scale, local to international scope addressing important social needs that are left out of the focus of laws, regulation, politics or even will, and, thus, filling the gaps in society. As social constructionists operate on a larger scale with actions that are scalable even to international scope, they require more financial and human resources than social bricoleurs. The third typology, social engineers, create new, ground-breaking social systems that replace the existing ones if they are not suitable for the social needs. Social engineers operate on a very large scale, from national to global scope, and they represent a very important force for social change. Therefore, they need greater resources and funding than the other two typologies and might face more resistance as the established actors hold on to power.

Typically, social entrepreneurship has been considered as 'entrepreneurial activity with an embedded social purpose' (Austin et al., 2006, p. 1) or 'the capacity to be both commercially viable and socially constructive' (Tracey \& Phillips, 2007, p. 265). In pursuing the dual mission, social entrepreneurs engage closely with beneficiaries demonstrating capacity of endurance, using market orientation, creating social capital, and being emancipatory in their 
work (Alvord et al., 2004; Choi and Majumdar, 2014; Doherty et al., 2014; Miller et al., 2012; Mort et al., 2003; Sengupta et al., 2018; Tan et al., 2005). Unlike for-profit companies, social enterprises focus on maximizing social value creation, while satisficing on economic value capture (Santos, 2012). The hybridity separates social enterprises from other organizations (Agafonow, 2014), as they exist not to compete for wealth-maximization, but primarily to benefit powerless communities (Santos, 2012).

Hybrid-organization identity and the hybrid-organizing mechanisms in social entrepreneurship (Battilana \& Lee, 2014) can inform new business models for transition to increased sustainability through crossbreeding social, economic, and environmental value creation. Todaro and Smith (2011) postulated that social value creation is an activity that is based on three core values of social development: building and maintaining self-esteem or, in other words, maintaining dignity; ensuring sustenance and ability to meet basic needs; and achieving freedom from servitude, such as exploitation at work and society. Auerswald (2009) suggested that social value creation consists of six dimensions: financial, reputational, ethical value, consumer surplus, positive externalities, and the enhancement of human capabilities. The financial value is for the economic sustainability of the enterprise. The reputational and ethical values create a genuine image of the enterprise in the market. Consumer surplus and enhancement of human capabilities should be the outcomes of an enterprise. Positive externalities would mean benefits created through outreach to those who are not directly related to the enterprise. Sinkovics et al. (2015) show that social value creation may be either an output variable, when disadvantaged people access a product or a service through monetary exchange, or an organic outcome, when social value is an outcome of the functions and business model of the enterprise. Such value may be detected in sustainable changes in the lives of beneficiaries and their communities and relationships with others.

In the case of social enterprises, social value creation is prioritized over profit making (Dees, 1998) while, for commercial enterprises, social value creation is more of a secondary output, or a by-product (Certo \& Miller, 2008). In social entrepreneurship, social value creation is achieved by successfully attending to complex and diverse social cause-attractors (Dietz \& Porter, 2012). It is an intervention creating positive change, i.e. social value, for subjective wellbeing and life satisfaction (Kroeger \& Weber, 2014) of people seeking subsistence, or freedom from subjection and enslavement (Sinkovics et al., 2015). It is not necessary that the social mission and economic mission of a social enterprise are always run with the same intensity. This results in identifying two kinds of entrepreneurs: a 'deeds social entrepreneur', who has more focus on the social cause-attractor, and a 'dollars social entrepreneur', who expedites social value creation by generating revenue (Vega \& Kidwell, 2007, p. 6).

\section{Social Entrepreneurs as Change Agents}

In social entrepreneurship, capacity to act is related to a strong sense of social purpose in the entrepreneur and the enterprise. Social entrepreneurs are portrayed as individuals with a strong social mission (Macke et al., 2018), passion for social change (Driver, 2017), and moral disposition (Tan et al., 2005), whereby they put the collective before self-interest. Social entrepreneurs are considered as altruistic and virtuous in promoting social purposes (Choi \& Majumdar, 2014). Critics claim that such an individualist view portrays social entrepreneurs as heroic entrepreneurs, and, thus, provides too simplified an understanding of social entrepreneurship (Nicholls \& Cho, 2006; Sud et al., 2009). There is, however, evidence that examining 
social entrepreneurs as individual change agents allows for directing attention to the ways by which social entrepreneurs come up with solutions that are not recognized or imposed by the government and the social sector. Attention to social entrepreneurs with a capacity to act allows for, for instance, examining how social entrepreneurs identify social problems and consider solutions through sensemaking (Kimmitt \& Muñoz, 2018), or how identity work of social entrepreneurs creates space for ethical agency and reimagining future economy (Driver, 2017). This perspective also allows for extending the notion of social entrepreneurs as agents who not only address social and economic sustainability but also environmental sustainability (Lehtimäki et al., 2020).

Addressing the sustainability agency of social entrepreneurs as situated in and shaped by contexts leads to a relational view of agency. In this view, social entrepreneurs are examined as embedded in locally and globally connected contexts. Entrepreneurs need to understand customer needs and preferences, financial and economic systems, and the political, cultural, and religious systems in which they operate. Simultaneously, as structurally and socially embedded agents entrepreneurs have an opportunity to create ventures with a social and environmental objective and a financially viable business model, and, thus, bring about change to the context through strategy and innovation (Rahdari et al., 2016; Zahra et al., 2009). As change agents, social entrepreneurs are both trying to understand the contextual dynamics and develop operational and socially and economically sustainable solutions (Dzombak et al., 2014).

\section{Sustainability in Social Entrepreneurship}

Social enterprises are important agents in non-governmental sustainability efforts in civil society (Rahdari et al., 2016), but the rationale of social enterprises varies from country to country, and attention to agency in the local context is important (Macke et al., 2018). Welfare states might intend to cut public expenditure and allocate social responsibilities to social enterprises while third world countries may seek to find sustainable solutions to poverty and social inclusion (Macke et al., 2018). From the policymaking point of view, social enterprises are formed because they can solve social and environmental problems more effectively and efficiently than governments, often through decentralizing development work (Plutshack et al., 2019). However, due to the contextual boundaries, social enterprises may be too focused on local innovations and advancing local initiatives and lack broader effects in national or international fields (Geels, 2020).

As sustainability agents, social enterprises are expected to be able to combine economic, social, and environmental elements (Macke et al., 2018; Sud et al., 2009). This blurs the distinction between for-profit and not-for-profit organizations and calls for new ways of measuring short-term and long-term business outcomes (Porter \& Kramer, 2006). Often, the primary target is to create social value, while economic value creation is secondary and serves the core mission of benefiting communities in need (Santos, 2012). Different methods of value creation are, however, intertwined. Economic value can be financial (economic) or non-financial (social and environmental) and both are fundamentally connected (Hlady-Rispal \& Servantie, 2018). A recent study on renewable energy social enterprises, which have both social and environmental objectives, found that the actions and voices of the enterprise and community actors enact social value creation and market orientation as converging logics rather than being a dilemma (Sengupta et al., 2020). What came out clearly was that, for the social enterprises, 
social and environmental sustainability through their day-to-day practice mattered more than trying to differentiate between what is market and what is social, which had unfortunately been a matter of contestation for many researchers with no substantial outcome. This reinforces the need for researching and practising social entrepreneurship with a sustainability agency perspective, rather than getting into a definitional or social vs. economic debate.

\section{CONCLUSIONS}

Social entrepreneurship literature does not talk about environmental value creation as central to what social entrepreneurs do. To explore this dimension, we drew upon literature that talks about connecting social entrepreneurship with sustainable entrepreneurship and literature on sustainability transitions. Sustainable enterprises have an environmentally relevant process of discovering, evaluating, and exploiting opportunities in market failures which dampen or slow down sustainability. As sustainability agents, social entrepreneurs cross the boundary from a double-bottom-line focus (social + market) to a triple-bottom-line focus (social + market + environment) (Figure 11.1).

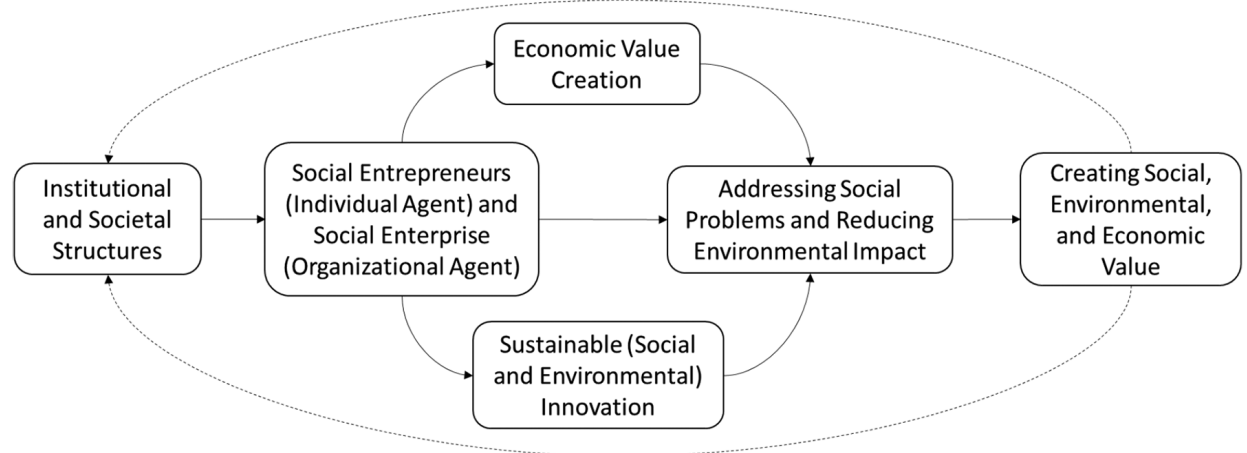

Figure 11.1 Social entrepreneurship as sustainability agency

As stated previously, the primary target of a social enterprise is to create social value, while economic value creation can be secondary to the core mission of benefiting communities in need (Santos, 2012). However, it can be argued, that environmental issues are both social and economic and, therefore, social entrepreneurs have a critical position as change agents in the wake of climate change and a sustainable circular economy. Creating social and environmental value can occur through radical or adaptive social innovations (Hlady-Rispal \& Servantie, 2018), which are both common in social entrepreneurship (Choi and Majumdar, 2014; Lehtimäki et al., 2020). Social innovations are novel developments, such as new business models, that bring more sustainable solutions compared to a current state of a certain issue (Phills et al., 2008). With social innovations social entrepreneurs may seek to tackle market failures (Zahra et al., 2008) or address social injustice and problems (Zahra et al., 2009; Saebi et al., 2019) or environmental issues by introducing sustainable innovation for reducing environmental impacts (Rahdari et al., 2016). 
Social enterprises are identified as hybrids because they create both social and economic value, at varying degrees. Non-financial performance can have a drastic effect on financial performance, that is, the more social entrepreneurs can create social and environmental value, the more there is a possibility to gain economic value (Parrish, 2010; Hlady-Rispal \& Servantie, 2018). Social entrepreneurship literature does not talk about environmental value creation as central to what social entrepreneurs do. But, as we see it, social entrepreneurship is crossing boundaries towards becoming sustainable entrepreneurship: in going from a double-bottom-line focus (social + market) to a triple-bottom-line focus (social + market + environment), social enterprises are being sustainability agents.

Our review highlights three interrelated aspects of sustainability agency in social entrepreneurship. First, sustainability agency is connected to the entrepreneur as an individual (agent), who pursues a social mission in business or not-for-profit operations. The social entrepreneur can be considered a sustainability agent in a Schumpeter's entrepreneurial sense, whereby an entrepreneur acts strategically and creatively to realize unseen or unused potential (Weik, 2011), in the case of a social entrepreneur, for sustainable value creation. Second, sustainability agency is related to the actions of the social enterprise that operates with a hybrid logic and is committed to creating multiple value. This view examines the sustainability agency of social enterprises from the perspective of institutional work (Weik, 2011), and maintains that sustainability agency resides in the actions and practices of organizing, interacting with the beneficiaries, connecting with stakeholders, and negotiating with the public and government organizations. Third, sustainability agency of social entrepreneurship is a matter of contextual embeddedness of the operations. Social enterprises operate in an institutional environment that has influenced the mission and vision of the operations, and that is being shaped by the operations. Social entrepreneurs can be considered to be institutional entrepreneurs (Weik, 2011) who operate in existing social structures, such as political context and power structures in the institutional environment, in such a way that the structures act as a medium for as well as outcomes of the agency of the social entrepreneurs. As institutional entrepreneurs, social entrepreneurs have the potential to break the institutional status quo of releasing sustainability from an elitist discourse to something that can be practised by social entrepreneurs in their business ventures with activities and processes creating social wealth.

Hence, for future research, we propose conducting an analysis of the agency of social entrepreneurship from the perspectives of institutional entrepreneurship, institutional work, and Schumpeterian entrepreneurship to increase our understanding about sustainable entrepreneurship and sustainability agency. Also, we note, due to the contested nature of the concept of social entrepreneurship, the sustainability agency of social entrepreneurship is best studied as situated in a national, cultural, and social context. Context-sensitive research on the sustainability agency of social enterprises allows for reflexivity and deepening understanding about the ways by which social enterprises join the large sustainability movement. Context-sensitive research on the micro-foundation of sustainability transition has the potential for a significant contribution.

To conclude, environmental issues are both social and economic, and, therefore, social entrepreneurs have a critical position as change agents addressing climate change and enhancing the sustainable circular economy in societies. The discussion we have presented provides a starting point for the nascent research on social entrepreneurs as sustainability agents. Social entrepreneurs are social agents creating and sustaining social value, but little is known about how social entrepreneurs create environmental value and what role social entrepreneurs play in creating and implementing new business opportunities in environmentally sustainable business. Sustainability principles can be introduced from top-down, when policymakers apply force in 
implementation, or bottom-up, when organizations innovate and make changes in their business operations (Ruggieri et al., 2016). The bottom-up view of sustainability directs attention to grassroots innovation in social entrepreneurship. Allocating agency to individuals and small businesses in sustainability transition highlights the active and creative engagement of actors in meaning-making (Geels, 2020) and allows for identifying social entrepreneurs as activists and creators of grassroots innovation in sustainability transition.

\section{ACKNOWLEDGEMENT}

The authors gratefully acknowledge the financial support from the Strategic Research Council at the Academy of Finland (decision number 320209), Foundation for Economic Education, Foundation for Private Entrepreneurs and The Paulo Foundation.

\section{NOTE}

1. This is an open access work distributed under the Creative Commons Attribution-NoDerivatives 4.0 International (CC BY-ND 4.0). Users can redistribute the work for non-commercial purposes, as long as it is passed along unchanged and in whole, as detailed in the License. Edward Elgar Publishing Ltd must be clearly credited as the rights holder for publication of the original work. Any translation or adaptation of the original content requires the written authorization of Edward Elgar Publishing Ltd.

\section{REFERENCES}

Agafonow, A. (2014), 'Toward a positive theory of social entrepreneurship: On maximizing versus satisficing value capture', Journal of Business Ethics, 125 (4), 709-713.

Alvord, S. H., Brown, L. D., and Letts, C. W. (2004), 'Social entrepreneurship and societal transformation: An exploratory study', Journal of Applied Behavioral Science, 40 (3), 260-282.

Auerswald, P. (2009), 'Creating social value', Stanford Social Innovation Review, 7 (2), 50-55.

Austin, J., Stevenson, H., and Wei-Skillern, J. (2006), 'Social and commercial entrepreneurship: Same, different, or both?', Entrepreneurship: Theory and Practice, 30 (1), 1-22.

Bacq, S., and Janssen, F. (2011), 'The multiple faces of social entrepreneurship: A review of definitional issues based on geographical and thematic criteria', Entrepreneurship \& Regional Development, 23 (5-6), 373-403.

Battilana, J., and Lee, M. (2014), 'Advancing research on hybrid organizing - Insights from the study of social enterprises', The Academy of Management Annals, 8 (1), 397-441.

Bocken, N. M., De Pauw, I., Bakker, C., and van der Grinten, B. (2016), 'Product design and business model strategies for a circular economy', Journal of Industrial and Production Engineering, 33 (5), 308-320.

Boschee, J. (1998), 'Merging mission and money: A board member's guide to social entrepreneurship', accessed 15 August 2020 at http://www.socialent.org/pdfs/MergingMission.pdf.

Bull, M., and Ridley-Duff, R. (2019), 'Towards an appreciation of ethics in social enterprise business models', Journal of Business Ethics, 159 (3), 619-634.

Certo, S. T., and Miller, T. (2008), 'Social entrepreneurship: Key issues and concepts', Business Horizons, 51 (4), 267-271.

Choi, N., and Majumdar, S. (2014), 'Social entrepreneurship as an essentially contested concept: Opening a new avenue for systematic future research', Journal of Business Venturing, 29 (3), 363-376.

Copestake, J., Dawson, P., Fanning, J. P., McKay, A., and Wright-Revolledo, K. (2005), 'Monitoring the diversity of the poverty outreach and impact of microfinance: A comparison of methods using data from Peru', Development Policy Review, 23 (6), 703-723. 
Dacin, P. A., Dacin, M. T., and Matear, M. (2010), 'Social entrepreneurship: Why we don't need a new theory and how we move forward from here', Academy of Management Perspectives, 24 (3), 37-57.

Dees, J. G. (1998), 'Enterprising nonprofits: What do you do when traditional sources of funding fall short', Harvard Business Review, 76 (1), 55-67.

Defourny, J., and Nyssens, M. (2010), 'Conceptions of social enterprise and social entrepreneurship in Europe and the United States: Convergences and divergences', Journal of Social Entrepreneurship, 1 (1), 32-53.

Dietz, A. S., and Porter, C. (2012), 'Making sense of social value creation: Three organizational case studies', Emergence: Complexity \& Organization, 14 (3), 23-43.

Doherty, B., Haugh, H., and Lyon, F. (2014), 'Social enterprises as hybrid organizations: A review and research agenda', International Journal of Management Reviews, 16 (4), 417-436.

Driver, M. (2017), 'Never social and entrepreneurial enough? Exploring the identity work of social entrepreneurs from a psychoanalytic perspective', Organization, 24 (6), 715-736.

Dzombak, R., Mehta, C., Mehta, K., and Bilén, S. G. (2014), 'The relevance of systems thinking in the quest for multifinal social enterprises', Systemic Practice and Action Research, 27 (6), 593-606.

European Commission (2020), Social Enterprises and their Ecosystems in Europe. Comparative Synthesis Report, Luxembourg: Publications Office of the European Union, accessed 15 August 2020 at https:// europa.eu/!Qq64ny.

Finlex (2020), Act on Social Enterprises, Finlex database, accessed 14 August 2020 at https://www.finlex .fi/en/laki/kaannokset/2003/en20031351.pdf.

Geels, F. W. (2020), 'Micro-foundations of the multi-level perspective on socio-technical transitions: Developing a multi-dimensional model of agency through crossovers between social constructivism, evolutionary economics and neo-institutional theory', Technological Forecasting and Social Change, 152, 119894.

Goyal, S., and Sergi, B. S. (2015), 'Social entrepreneurship and sustainability - understanding the context and key characteristics', Journal of Security \& Sustainability Issues, 4 (3), 269-278.

Helmsing, A. B. (2015), 'Conditions for social entrepreneurship', The International Journal of Social Quality, 5 (1), 51-66.

Hill, T., Kothari, T., and Shea, M. (2010), 'Patterns of meaning in the social entrepreneurship literature: A research platform', Journal of Social Entrepreneurship, 1 (1), 5-31.

Hlady-Rispal, M., and Servantie, V. (2018), 'Deconstructing the way in which value is created in the context of social entrepreneurship', International Journal of Management Reviews, 20 (1), 62-80.

Hota, P. K., Subramanian, B., and Narayanamurthy, G. (2019), 'Mapping the intellectual structure of social entrepreneurship research: A citation/co-citation analysis', Journal of Business Ethics, 166 (1), 89-114.

Kapitan, S., Kennedy, A., and Berth, N. (2019), 'Sustainably superior versus greenwasher: A scale measure of B2B sustainability positioning', Industrial Marketing Management, 76, 84-97.

Kimmitt, J., and Muñoz, P. (2018), 'Sensemaking the "social" in social entrepreneurship', International Small Business Journal, 36 (8), 859-886.

Kittilaksanawong, W., Hu, C. S., Shou, Y. Y., and Chen, X. D. (2012), 'Institutionalization in organizational form of social entrepreneurship: Cases from China and Bangladesh', in 2012 IEEE International Conference on Management of Innovation \& Technology (ICMIT), Bali, Indonesia (pp. 39-44). DOI: 10.1109/ICMIT.2012.6225776.

Kroeger, A., and Weber, C. (2014), 'Developing a conceptual framework for comparing social value creation', Academy of Management Review, 39 (4), 513-540.

Lehtimäki, H., Piispanen, V.-V., and Sengupta, S. (2020), 'Social entrepreneurship as a cluster concept: Is a cricket farming start-up a social enterprise?', Journal of Asia Entrepreneurship and Sustainability, 16 (2), 162-186.

Macke, J., Sarate, J. A. R., Domeneghini, J., and Aparecida da Silva, K. (2018), 'Where do we go from now? Research framework for social entrepreneurship', Journal of Cleaner Production, 183, 677-685.

Massetti, B. L. (2008), 'The social entrepreneurship matrix as a "tipping point" for economic change', Emergence: Complexity and Organization, 10 (3), 1-8.

Miller, T. L., Grimes, M. G., McMullen, J. S., and Vogus, T. J. (2012), 'Venturing for others with heart and head: How compassion encourages social entrepreneurship', Academy of Management Review, 37 (4), 616-640.

Mook, L., Maiorano, J., Ryan, S., Armstrong, A., and Quarter, J. (2015), 'Turning social return on investment on its head: The stakeholder impact statement', Nonprofit Management and Leadership, 26 (2), 229-246. 
Mort, S. G., Weerawardena, J., and Carnegie, K. (2003), 'Social entrepreneurship: Towards conceptualisation', International Journal of Nonprofit and Voluntary Sector Marketing, 8 (1), 76-88.

Nicholls, A., and Cho, A. (2006), 'Social Entrepreneurship: The Structuration of a Field', in A. Nicholls (ed.), Social Entrepreneurship: New Models of Sustainable Social Change (pp. 99-118), Oxford: Oxford University Press.

Parrish, B. D. (2010), 'Sustainability-driven entrepreneurship: Principles of organization design', Journal of Business Venturing, 25 (5), 510-523.

Phills, J., Deiglmeir, K., and Miller, D. (2008), 'Rediscovering social innovation', Stanford Social Innovation Review, 6, 34-43.

Plutshack, V., Sengupta, S., Sahay, A., and Viñuales, J. E. (2019), 'New and renewable energy social enterprises accessing government support: Findings from India', Energy Policy, 132, 367-378.

Porter, M. (2008), Competition, Boston, MA: Harvard Business School Publishing.

Porter, M., and Kramer, M. (2006), 'Strategy \& society: The link between competitive advantage and corporate social responsibility', Harvard Business Review, December, 78-93.

Rahdari, A., Sepasi, S., and Moradi, M. (2016), 'Achieving sustainability through Schumpeterian social entrepreneurship: The role of social enterprises', Journal of Cleaner Production, 137, 347-360.

Reiser, D. B., and Dean, S. A. (2013), 'Hunting stag with flypaper: A hybrid financial instrument for social enterprise', BCL Review, 54 (4), 1495-1544.

Ruggieri, A., Braccini, A., Poponi, S., and Mosconi, E. (2016), 'A meta-model of inter-organisational cooperation for the transition to a circular economy', Sustainability, 8 (11), 1153-1170.

Saebi, T., Foss, N. J., and Linder, S. (2019), 'Social entrepreneurship research: Past achievements and future promises', Journal of Management, 45 (1), 70-95.

Santos, F. M. (2012), 'A positive theory of social entrepreneurship', Journal of Business Ethics, 111 (3), 335-351.

Sengupta, S., Sahay, A., and Croce, F. (2018), 'Conceptualizing social entrepreneurship in the context of emerging economies: An integrative review of past research from BRIICS', International Entrepreneurship and Management Journal, 14 (4), 771-803.

Sengupta, S., Sahay, A., and Hisrich, R. D. (2020), 'The social-market convergence in a renewable energy social enterprise', Journal of Cleaner Production, 270, 122516.

Sinkovics, N., Sinkovics, R. R., Hoque, S., and Czaban, L. (2015), 'A reconceptualisation of social value creation as social constraint alleviation', Critical Perspectives on International Business, 11 (3/4), 340-363.

Sud, M., VanSandt, C. V., and Baugous, A. M. (2009), 'Social entrepreneurship: The role of institutions', Journal of Business Ethics, 85 (1), 201-216.

Tan, W. L., Williams, J., and Tan, T. M. (2005), 'Defining the "social" in "social entrepreneurship": Altruism and entrepreneurship', International Entrepreneurship and Management Journal, 1 (3), 353-365.

Todaro, M. P., and Smith, S. C. (2011), Economic Development, London: Pearson Education.

Tracey, P., and Phillips, N. (2007), 'The distinctive challenge of educating social entrepreneurs: A postscript and rejoinder to the special issue on entrepreneurship education', Academy of Management Learning \& Education, 6 (2), 264-271.

Uygur,U., and Marcoux, A.M.(2013), 'The added complexity of social entrepreneurship: A knowledge-based approach', Journal of Social Entrepreneurship, 4 (2), 132-152.

Vega, G., and Kidwell, R. E. (2007), 'Toward a typology of new venture creators: Similarities and contrasts between business and social entrepreneurs', New England Journal of Entrepreneurship, 10 (2), Art. 4.

WCED (World Commission on Environment and Development) (1987), Our Common Future, Oxford: Oxford University Press.

Weik, E. (2011), 'Institutional entrepreneurship and agency', Journal for the Theory of Social Behaviour, 41 (4), 466-481.

Zahra, S. A., Gedajlovic, E., Neubaum, D. O., and Shulman, J. M. (2009), 'A typology of social entrepreneurs: Motives, search processes and ethical challenges', Journal of Business Venturing, 24 (5), 519-532.

Zahra, S. A., Rawhouser, H. N., Bhawe, N., Neubaum, D. O., and Hayton, J. C. (2008), 'Globalization of social entrepreneurship opportunities', Strategic Entrepreneurship Journal, 2 (2), 117-131.

Zainon, S., Ahmad, S. A., Atan, R., Wah, Y. B., Bakar, Z. A., and Sarman, S. R. (2014), 'Legitimacy and sustainability of social enterprise: Governance and accountability', Procedia-Social and Behavioral Sciences, 145, 152-157.

Zietlow, J. T. (2001), 'Social entrepreneurship: Managerial, finance and marketing aspects', Journal of Nonprofit \& Public Sector Marketing, 9 (1-2), 19-43. 